\title{
Exploring Resources and Performance Relationships in Commercial Enterprises: An Empirical Perspective
}

\author{
Beatrice E. Ombaka ${ }^{1}$, Zachary Bolo Awino ${ }^{2}$, Vincent N. Machuki ${ }^{2}$ \& Gituro Wainaina ${ }^{2}$ \\ ${ }^{1}$ School of Business, Karatina University, Kenya \\ ${ }^{2}$ School of Business, Nairobi University, Kenya \\ Correspondence: Zachary Bolo Awino, School of Business, Nairobi University, Nairobi, Kenya.
}

Received: July 21, 2015

doi:10.5430/jms.v6n4p12
Accepted: August 18, 2015

Online Published: October 7, 2015

URL: http://dx.doi.org/10.5430/jms.v6n4p12

\begin{abstract}
Despite a growing body of literature on firm performance, explaining why firms in the same industry and markets differ in their performance remains a fundamental question within strategic management field. Researchers have attributed differences in firm performance to resources owned by a firm but the results remain fragmented and no consensus has yet emerged.Therefore, the debate is still open and this study sought to contribute to the debate and address extant gaps. This study investigated the influence of organizational resources on performance of insurance companies in Kenya. The study was based on a survey of 46 insurance companies in Kenya. The study reports that both tangible and intangible resources have a statistically significant influence on non-financial performance of insurance companies in Kenya. However, there were mixed findings as regards the individual influence of resources on various firm performance indicators. Intangible resources evidenced statistically not significant results individually but when combined, they had a statistically significant influence on non-financial performance. The reverse was true for tangible resources. Based on the findings, implications of the study and suggestions for further study are presented.
\end{abstract}

Keywords: organizational resources, firm performance, insurance companies, Kenya

\section{Introduction}

Strategic management scholars and practitioners have concerned themselves with explaining why firms in the same industry differ in performance. This has inconclusively been attributed to resources (Barney, 1986; Barney, 1991; Amit and Schoemaker, 1993; Kraatz and Zajac, 2001). Amit and Schoemaker (1993) proposed that firms in the same industry performed differently because they differ in terms of the resources and capabilities they control even in equilibrium. Empirical research has sought to explain the relationship between resources and performance but the results remain fragmented and no consensus has yet emerged (Barney, 1991; Amit and Schoemaker, 1993). This study therefore sought to establish the influence of organizational resources on performance of insurance companies in Kenya.

Resources are underpinned by the Resource Based Theory (RBT) (Barney, 1991) and the Dynamic Capabilities Theory (DCT) (Teece, Pisano and Shuen, 1997). The key postulation of the RBT is that the unique configuration and bundling of resources in competitive markets leads to Competitive Advantage (CA) and improved organizational performance (Barney, 1991). The DCT is an extension of the RBT and it posits that the competitive advantage of firms rests on distinctive processes, shaped by the firm's specific asset positions and the evolution path(s) it has adopted (Teece et al., 1997).

According to Porter (1991), firm performance has been fundamental in strategy research for decades and the focus has been why firms differ in performance. Hofer (1983) contends that performance is a contextual concept associated with the phenomenon being studied. Historically, firm performance was seen to be a function of factors outside the organization. More recently, there has been a paradigm shift with scholars arguing that firm performance is affected by organizational factors. Zott (2003) proposed that firm performance is affected by its ability to integrate, build and reconfigure capabilities and competences. Soh (2003) posits that firms with a more efficient networking strategy will acquire more competitive information about other firms. This information advantage in turn leads to better new product performance and improved overall performance of the firm (Soh, 2003). 
Historically, financial measures have been used to measure firm performance. These include profit, return on investment, earnings per share, market share, revenue growth and current ratio (Pandey, 1999; Neely, 2003). Dess and Robinson (1984) propose that regardless of the framework chosen to conceptualize firm performance, they argue that firm performance is a complex and multidimensional phenomenon difficult to measure.The constituency approach views the organization as existing to benefit numerous constituents both internal and external to the organization. Its focus is to fulfill constituents needs (Thompson, 1967).

Critics have expressed dissatisfaction with exclusive use of financial data to measure performance. They argue that use of financial data encourages short term and local optimization thus overlooking the long term improvement strategy and ignoring competitor information (Kaplan and Norton, 1992). Due to the inefficiencies of financial measures of performance, the Balanced Scorecard (BSC) (Kaplan and Norton, 1992) which has a more stakeholder-based view was developed. The BSC evaluates corporate performance from four perspectives namely financial, internal business processes, customers and learning and growth. According to the BSC, the firm is seen as having responsibilities to a wider set of groups than simply shareholders (Freeman, 1984).

Over the years, performance has evolved to encompass wider definitions and philosophies such as Profit Impact of Marketing Strategy (PIMS). This is grounded on the premise that firms are responsible for more than just creating economic value. In 1997, the Triple Bottom Line (TBL) was developed as a tool for measuring organizational performance (Elkington, 1997). The TBL considers excellence along all the three lines of sustainable reporting (economic, social and environmental) (Hubbard, 2009). The TBL adds social and environmental measures of performance to the economic measures used in organizations.

\section{Literature Review}

Resources owned and controlled by a firm are considered as determinants of superior firm performance. Strategic management scholars (Barney, 1991; Marino, 1996) have defined organizational resources as assets, knowledge, capabilities and organizational processes. These resources enable the firm to visualize and implement strategic decisions. Resources are input into the production process and can be tangible or intangible. Tangible resources include the financial and physical assets that are identified and valued in a firm's financial statements. These include capital, factories, machines, raw materials and land (Itami, 1987). Intangible resources are more difficult to measure, evaluate and transfer and include employee's knowledge, experiences and skills, firm's reputation, brand name and organizational procedures (Johnson et al., 2008). These attributes of intangible resources make them firm specific thus difficult to imitate. It is thus plausible to argue that they confer to the firm superior performance as compared to tangible resources.

Pioneering the work on resources was Penrose (1959) who posited that firms performed differently because of the way they deployed their bundle of resources. Rubin (1973) contends that resources are not of much use on their own and that firms must process raw resources to make them useful. Building on the works of earlier researchers, Barney (1991) proposed that resources and capabilities should be heterogeneous and imperfectly mobile, valuable and rare to be a source of Sustainable Competitive Advantage (SCA).

According to Baxter and Matear (2004), a firm's resources can be classified as either tangible or intangible or a combination of both. Similarly, Kostopoulos, Spanos and Prastacos (2002) have classified resources as tangible (financial or physical) or intangible (employee's knowledge, experiences and skills, firm's reputation, brand name, organizational procedures). Kapelko (2009) argues that there is lack of a unified definition and a general classification of intangible resources. She argues that various researchers have classified intangible resources differently.

Stewart (1997) views intangible assets as knowledge, information, experience and intellectual property while Hendricksen and Van Breda (1992) opine that intangible resources are patents, brand names, Research and Development (R\&D) and advertising. The RBV focuses on intangible resources as a source of a firm's SCA. Recent research has shifted focus from tangible to intangible resources because they are thought to be valuable, rare and difficult to imitate leading to a SCA (Barney, 1991). Empirical and theoretical literature proposeintangible resources as the drivers of a firm's superior performance (Amit and Schoemaker, 1993). In his empirical study of an Iranian company, Hall (1992) argues that intangible resources are a source of a firm's exceptional performance because they are a source of heterogeneity and have high barriers to duplication.

The RBT proposes that a firm's reputation, culture, knowledge and managerial skills (Carmeli and Tishler, 2004b) can lead to a CA. Reputation has been classified as a strategic intangible resource. Barnett, Jermier and Lafferty (2006) suggest that reputation accrue as an asset through three stages they identify as awareness, assessment and consolidation. The totality of this assessment yields the image which the organization becomes associated with.Argenti and 
Druckenmiller (2009) propose that when an organization's reputation is good, it is said that it has a reputational asset (a high intangible value). Cultivating a strong reputation is a necessary foundation for today's firms that intend to beat competition, enhance their market outlook and financial performance as well as sustained existence.

Ahangar (2011) posits that in the current knowledge economy, intangible or intellectual assets have been recognized as prominent resources. He contends that currently, firms are mainly driven by technology, knowledge, expertise and relations with stakeholders collectively known as Intellectual Capital (IC). Edvinsson and Malone (1997) define IC as the possession of knowledge, applied experience, organizational technology, customer relations and professional skills that provide a company with a competitive edge in the market.Bornemann (1999) established that enterprises which managed their IC better, achieved stronger competitive advantage than general enterprises.

Firms are also recognizing the importance of environmental threats such as the climatic change due to the warming of the earth's atmosphere. Consequently, firms are developing strategies and programs to create products and production processes that are more environment friendly. Hunt and Auster (1990) argue that top management involvement in environment management demonstrates the importance given to the environment by the organization. Employees have a responsibility of ensuring that environment management is achieved by their firm (Berry \&Rondinelli, 1998). For better performance, employees should be involved in the environmental decisions and in the process of continuous improvement of environmental performance (Florida, 1996).

Another important intangible resource is knowledge and as a strategic resource, employees' knowledge has been thought to be an important determinant of a firm's success (Nonaka, 1994). Nonaka and Takeuchi (1995) identified two types of knowledge namely explicit knowledge and tacit knowledge. According to them, explicit knowledge refers to structured and codified knowledge that is formal, systematic and easily expressed in the production specifications, scientific formulae or computer programs (Nonaka and Konno, 1998). Conversely, tacit knowledge is unconsciously understood and applied, difficult to articulate and developed directly from experience, and action (Zack, 1999).

Barney (1986) definesorganizational culture as a complex set of values, beliefs, assumptions and symbols that define the way in which a firm conducts its business. Schein (2004) posits that organizational culture consists of two layers of concepts, namely, visible and invisible characteristics. The invisible layer consists of buildings, clothing and behaviour modes while the invisible layer consists of values, norms, faith and assumptions of business organization members.Schein (2004) argues that culture can help organizations adapt well to the external environment for rapid and appropriate responses.Peters and Waterman (1982) proposed that firms' with strong cultures had excellent management. Consequently, firms with superior performance were believed to have strong managerial values. However, Barney (1986) proposes that for culture to be a source of SCA, it must be valuable, rare and imperfectly imitable.

Bakar and Ahmad (2010) propose that tangible resources include capital, location of buildings, warehouse and other facilities. Conner (2002) argues that tangible resources are a weak source of competitive advantage compared to intangible resources as competitors can easily duplicate them.Chatterjee and Wernerfelt (1984) contend that tangible assets are firm as well as usage specific and are used in a limited number of activities. Jugdev and Mathur (2012) propose that while tangible resources such as hardware, software, systems, methodologies and bodies of knowledge are valuable, they are imitable and unlikely to create a SCA for a firm.

Dierickx and Cool (1989) and Peteraf (1993) posit that the reason why tangible resources fail to meet the necessary conditions to be a critical factor of competitive advantage is the lack of value, heterogeneity, rareness, durability, imperfect mobility, unsubstitutability and imperfect imitability. Barney (1997) observed that tangible resources could be a source of advantage if they were obtained to a sufficient extent and if they had economies of scale (Clarke, 1988).

According to Barney (1997), tangible assets include company's land, geographical location, infrastructure, assets such as buildings, ICT, physical networks and other equipment, as well as access to raw materials and energy. Availability of capital has been found to be positively related to firm formation (Gartner, 1985) and to firm growth (Castrogiovanni, 1991). However, Farjoun (1998) contends thatthat tangible resources are limited in the range of industries in which they can be applied. Chatterjee\&Wernerfelt (1991) support this notion and argue that there are limitations in reusing tangible resources. In order for firms to prosper, they should have a combination of both tangible and intangible assets.

\section{Methods and Results}

This study used a cross-sectional survey to collect primary data. Nachmias and Nachmias (2004) argue that cross-sectional surveys help a researcher establish whether significant associations among variables exist at some point in time. Cooper and Schindler (2006) pointed out that cross sectional studies are carried out once. For purposes of this study, all the 46 insurance companies in Kenya were targeted thus making it a census survey. 
Both primary and secondary data were collected. Primary data on resources and the qualitative measures of firm performance were obtained through a structured questionnaire and an interview guide. Data on qualitative measures of firm performance were gathered using a 5 point Likert type scale consisting of customer perspective, internal business processes, learning and growth, environment aspect and corporate social responsibility. Data on quantitative measures of performance (profit before tax and premium) were obtained from published sources, that is, the AKI annual reports of 2010-2012.The study used a 3 year data because there had been reorganization of insurance businesses in to life and non life and so most of the companies had complete data for three years. The target respondents were senior managers of insurance companies and the study targeted Chief Executive Officers (CEO) or designated director, head of department, general manager or line managers. The senior managers were picked from either marketing department or strategy and risk departments. These respondents were best placed to answer the questionnaire as they were thought to be knowledgeable and define the direction of the organization.

The objective of the study was to establish the influence of organizational resources on performance of insurance companies in Kenya. The following hypotheses were formulated for testing.

\section{$H_{01}$ : There is no statistically significant influence of resources on performance of insurance companies in Kenya. \\ $H_{01 a}:$ Tangible resources do not have a statistically significant influence on performance of insurance companies in Kenya.}

To address the sub hypotheses, independent influence of tangible resources (physical resources and financial resources) was tested first on various performance indicators (premium, profit, customer perspective, internal business processes, learning and growth, environmental aspect and CSR). The second part addressed the combined effect of tangible resources on the above performance measures. Lastly, the composite index of non-financial firm performance measures was regressed on the composite index of tangible resources measures.

Table 1 shows regression results for the influence of tangible resources on premium. The coefficient of determination was 0.303 indicating that 30.3 percent of variation in premium growth was explained by tangible resources. The remaining 69.7 percent was explained by other factors not considered in the study.

Table 1. Influence of tangible resources on premium

\begin{tabular}{lllllll}
\hline Model & R & R Square & Adjusted R Square & \multicolumn{2}{l}{ Std. Error of the Estimate } \\
\hline 1 & $.551^{\mathrm{a}}$ & .303 & .252 & & .27968 & \\
\hline ANOVA & \multicolumn{7}{c}{ Sum of Squares } & $\mathrm{df}$ & Mean Square & F-value & Sig. \\
\hline Model & & .919 & 2 & .460 & 5.875 & $.008^{\mathrm{a}}$ \\
\hline 1 & Regression & .919 & .078 & & \\
& Residual & 2.112 & 27 & & & \\
& Total & 3.031 & 29 & & & \\
\end{tabular}

Coefficients

\begin{tabular}{lllllll}
\hline \multirow{2}{*}{ Model } & & \multicolumn{3}{c}{ Unstandardized Coefficients } & \multicolumn{2}{l}{ Coefficients } \\
\cline { 3 - 5 } & & $\mathrm{B}$ & Std. Error & Beta & t-value & Sig. \\
\hline 1 & (Constant) & 1.535 & .396 & & 3.874 & .001 \\
& Physical Resources & -1.569 & .500 & -.564 & -3.140 & .004 \\
& Financial Resources & 1.154 & .438 & .473 & 2.635 & .014 \\
\hline
\end{tabular}

A. Predictors: (Constant), Financial Resources, Physical Resources

B. Dependent Variable: Premium 
The overall model had a p-value of 0.008 , which revealed a statistically significant model. This means that tangible resources have a statistically significant influence on premium.

Table 2 shows regression results for influence of tangible resources on profit.

Table 2. Influence of tangible resources on profitbefore tax

\begin{tabular}{|c|c|c|c|c|c|c|c|}
\hline Model & $\mathrm{R}$ & R Square & \multicolumn{2}{|c|}{ Adjusted R Square } & \multicolumn{3}{|c|}{ Std. Error of the Estimate } \\
\hline 1 & $.275^{\mathrm{a}}$ & .076 & .005 & & \multicolumn{3}{|c|}{2.10542} \\
\hline \multicolumn{8}{|c|}{ ANOVA } \\
\hline Model & & Sum & Squares & $\mathrm{df}$ & Mean Square & F-value & Sig. \\
\hline \multirow[t]{3}{*}{$\overline{1}$} & Regression & 9.43 & & 2 & 4.717 & 1.064 & $.360^{\mathrm{a}}$ \\
\hline & Residual & 115 & & 26 & 4.433 & & \\
\hline & Total & 124 & & 28 & & & \\
\hline
\end{tabular}

A. Predictors: (Constant), Financial Resources, Physical Resources

B. Dependent Variable: Profit

The coefficient of determination was 0.076 which indicate that only 7.6 percent of variation in profit was explained by tangible resources. The remaining 92.4 percent was explained by other factors not considered in the study. The overall model had a p-value of 0.360 , which indicated that tangible resources have a statistically not significant influence on profit.

Table 3 shows regression results for the influence of tangible resources on customer perspective.

Table 3. Influence of tangible resources on customer perspective

\begin{tabular}{|c|c|c|c|c|c|c|c|}
\hline \multirow{2}{*}{$\begin{array}{l}\text { Model } \\
1 \\
\end{array}$} & \multirow{2}{*}{$\begin{array}{l}\mathrm{R} \\
.351^{\mathrm{a}}\end{array}$} & R Square & \multicolumn{2}{|c|}{ Adjusted R Square } & \multicolumn{3}{|c|}{ Std. Error of the Estimate } \\
\hline & & .124 & .063 & & & & \\
\hline \multicolumn{8}{|c|}{ ANOVA } \\
\hline Model & & Sum of & quares & $\mathrm{df}$ & Mean Square & F-value & Sig. \\
\hline \multirow[t]{3}{*}{1} & Regression & .040 & & 2 & .020 & 2.044 & $.148^{\mathrm{a}}$ \\
\hline & Residual & .286 & & 29 & .010 & & \\
\hline & Total & .326 & & 31 & & & \\
\hline
\end{tabular}

A. Predictors: (Constant), Financial Resources, Physical Resources

B. Dependent Variable: Customer Perspective

The coefficient of determination was 0.124 which indicated that only 12.4 percent of variation in customer perspective was explained by tangible resources. The remaining 77.6 percent was explained by other factors not considered in the study. The overall model had a p-value of 0.148 . The results indicate a statistically not significant model and so tangible resources have a statistically not significant influence on customer perspective. 
Table 4 shows regression results for the influence of tangible resources on internal business processes.

Table 4. Influence of tangible resources on internal business processes

\begin{tabular}{|c|c|c|c|c|c|c|c|c|c|}
\hline Model & $\mathrm{R}$ & R Square & \multicolumn{3}{|c|}{ Adjusted R Square } & \multicolumn{4}{|c|}{ Std. Error of the Estimate } \\
\hline 1 & $.468^{\mathrm{a}}$ & .219 & \multicolumn{3}{|l|}{.165} & \multicolumn{4}{|c|}{.10561} \\
\hline \multicolumn{10}{|c|}{ ANOVA } \\
\hline Model & & \multicolumn{2}{|c|}{ Sum of Squares } & $\mathrm{df}$ & \multicolumn{2}{|c|}{ Mean Square } & F-value & \multicolumn{2}{|l|}{ Sig. } \\
\hline \multirow[t]{3}{*}{$\overline{1}$} & Regression & .091 & & 2 & .045 & & 4.069 & $.028^{\mathrm{a}}$ & \\
\hline & Residual & .323 & & 29 & .011 & & & & \\
\hline & Total & .414 & & 31 & & & & & \\
\hline \multicolumn{10}{|c|}{ Coefficients } \\
\hline & & & \multicolumn{3}{|c|}{ Unstandardized Coefficients } & \multicolumn{2}{|c|}{$\begin{array}{l}\text { Standardized } \\
\text { Coefficients }\end{array}$} & & \\
\hline Model & & & \multicolumn{2}{|l|}{$\mathrm{B}$} & Std. Error & \multicolumn{2}{|l|}{ Beta } & t-value & Sig. \\
\hline \multirow[t]{3}{*}{$\overline{1}$} & (Constant) & & .366 & & .140 & & & 2.608 & .014 \\
\hline & Physical Res & sources & .098 & & .181 & .101 & & .543 & .591 \\
\hline & Financial Re & sources & .363 & & .164 & .411 & & 2.207 & .035 \\
\hline
\end{tabular}

A. Predictors: (Constant), Financial Resources, Physical Resources

B. Dependent Variable: Internal Processes

The coefficient of determination was 0.219 which indicate that 21.9 percent of variation in internal business processes was explained by tangible resources. The remaining 78.1 percent was explained by other factors not considered in the study. The overall model had a p-value of 0.028 and the results reveal a statistically significant model indicating that tangible resources had a statistically significant influence internal business processes.

Table 5 shows regression results for the influence of tangible resources on learning and growth.

Table 5. Influence of tangible resources on learning and growth

\begin{tabular}{lllllll}
\hline Model & $\mathrm{R}$ & R Square & Adjusted R Square & \multicolumn{2}{l}{ Std. Error of the Estimate } \\
\hline 1 & $.410^{\mathrm{a}}$ & .168 & .111 & & .09093 & \\
\hline ANOVA & \multicolumn{7}{c}{ Sum of Squares } & $\mathrm{df}$ & Mean Square & F-value & Sig. \\
\hline Model & & 2 & .024 & 2.936 & $.069^{\mathrm{a}}$ \\
\hline 1 & Regression & .049 & 29 & .008 & & \\
& Residual & .240 & 31 & & & \\
& Total & .288 & 29 & & & \\
\end{tabular}

A. Predictors: (Constant), Financial Resources, Physical Resources

B. Dependent Variable: Learning and Growth

The coefficient of determination was 0.168 which indicate that 16.8 percent of variation in learning and growth was explained by tangible resources. The remaining 83.2 percent was explained by other factors not considered in the study. The results also indicated a statistically not significant model $(\mathrm{p}$-value $=0.069)$. This indicates that tangible resources had a statistically not significant influence on learning and growth. 
Table 6 shows regression results for the influence of tangible resources on environment aspect.

Table 6. Influence of tangible resources on environment aspect

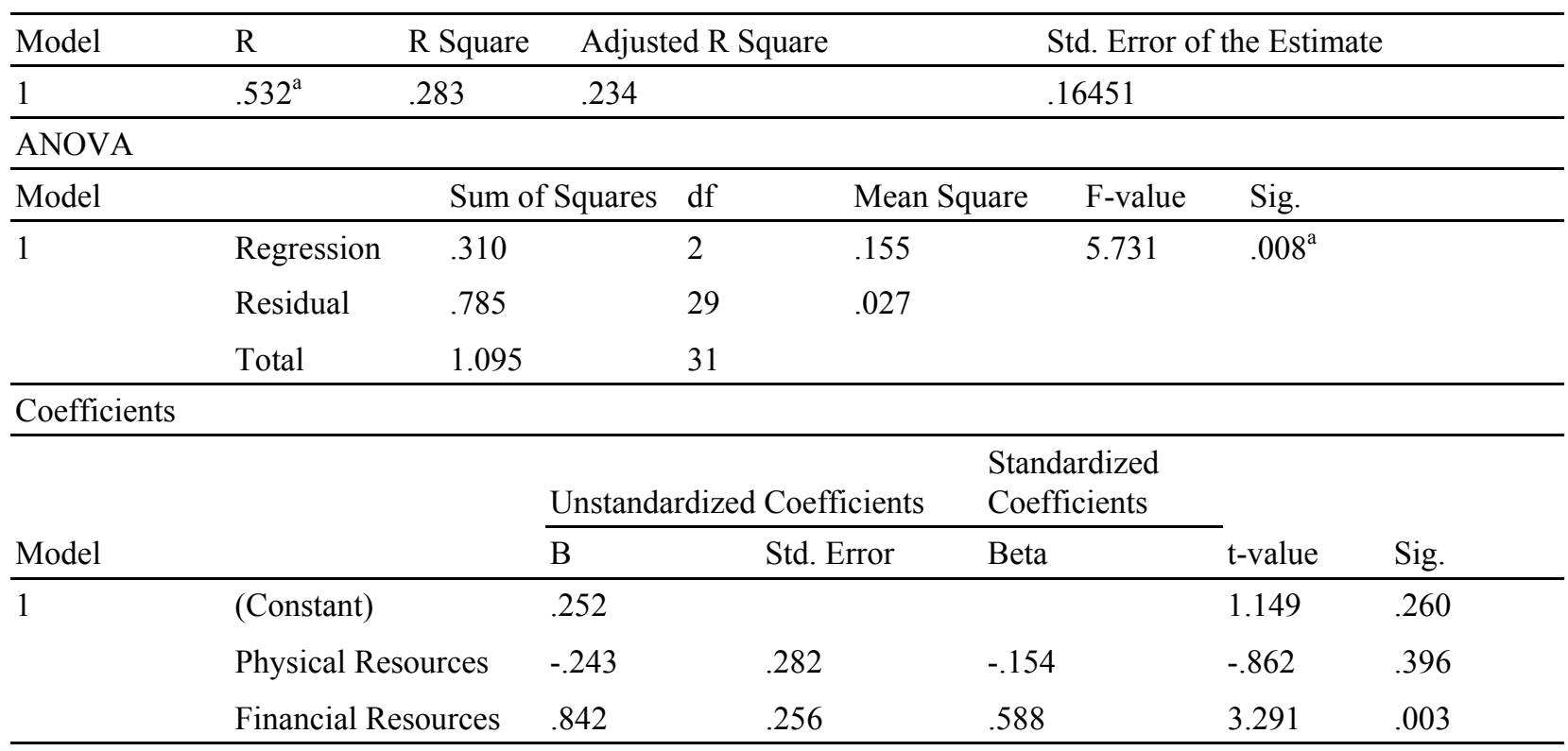

A. Predictors: (Constant), Financial Resources, Physical Resources

B. Dependent Variable: Environment Aspect

The coefficient of determination was 0.283 indicating that 28.3 percent of variation in environment aspect was explained by tangible resources. The remaining 71.7 percent was explained by other factors not considered in this study. The results indicate a statistically significant model $(\mathrm{p}$-value $=0.008)$ indicating that tangible resources have a statistically significant influence on environment aspect.

Table 7 shows regression results for the influence of tangible resources on social responsibility.

Table 7. Influence of tangible resources on corporate social responsibility

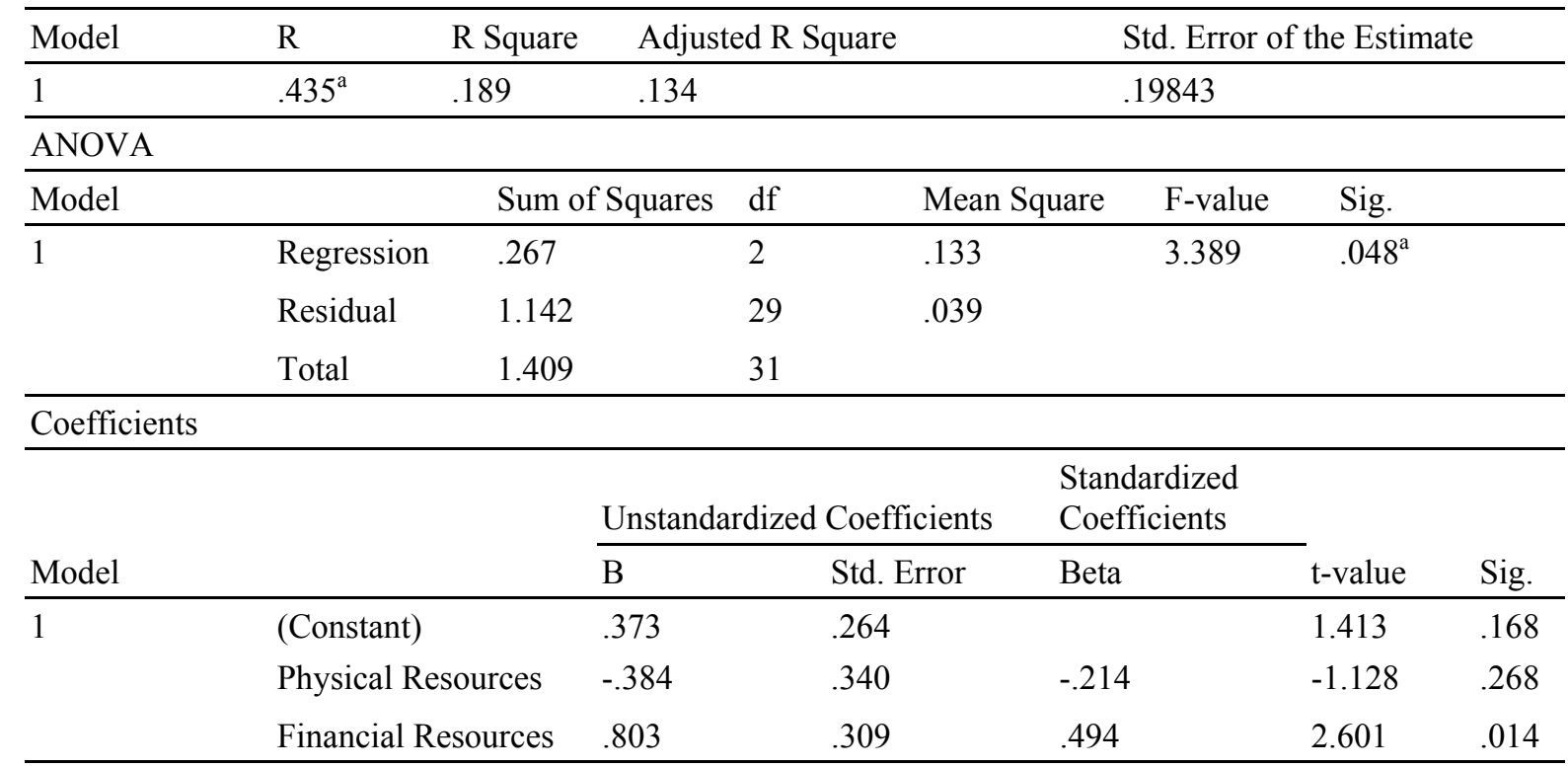

\section{A. Predictors: (Constant), Financial Resources, Physical Resources}

B. Dependent Variable: Corporate Social Responsibility 
The coefficient of determination was 0.189 indicating that 18.9 percent of variation in social responsibility was explained by tangible resources. The remaining 81.1 percent was explained by other factors not considered in the study. The results indicate a statistically significant model $(\mathrm{p}$-value $=0.048)$ and therefore tangible resources have a statistically significant influence on social responsibility.

After establishing the individual and combined effects, a composite index was computed for tangible resources and regressed on the composite index of all the non-financial performance indicators to establish the influence of tangible resources on non-financial firm performance and the results are shown in Table 8.

Table 8. Influence of tangible resources on non-financial firm performance

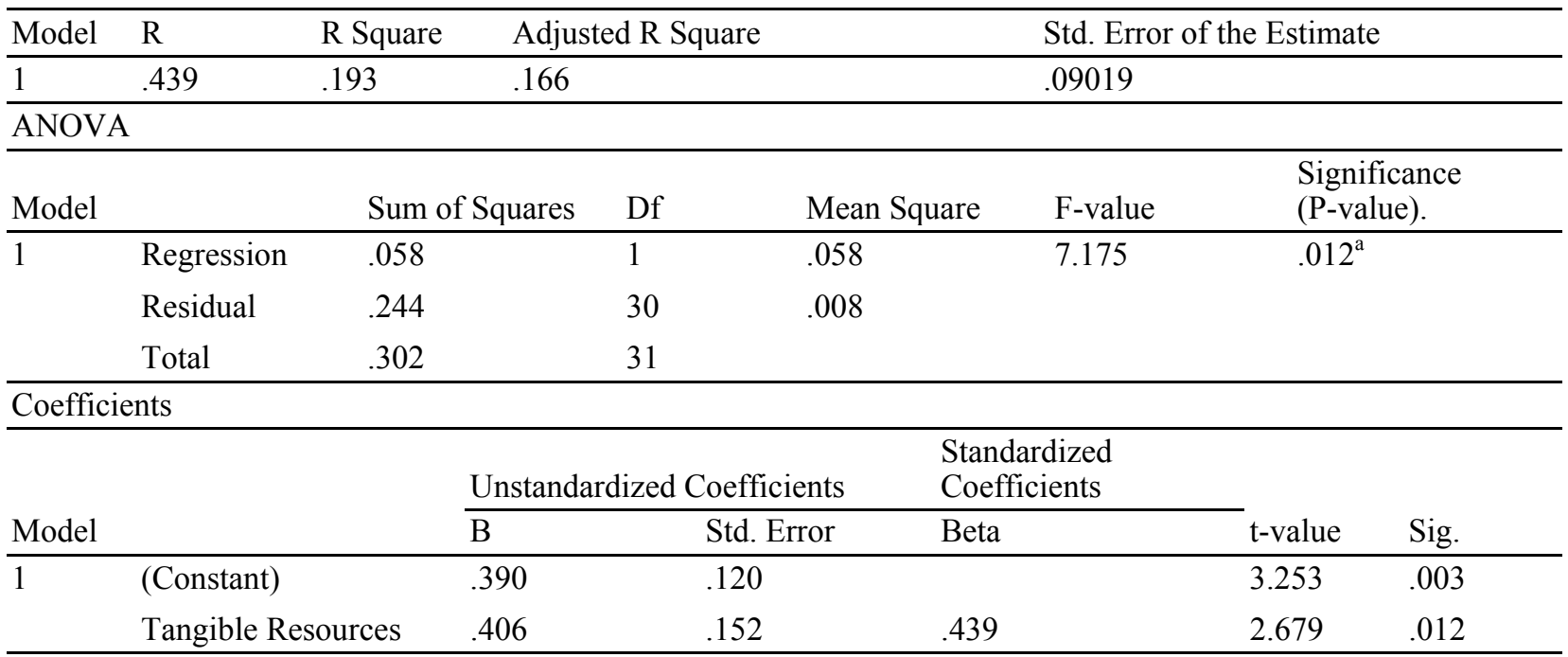

a. Predictors: (Constant), Tangible Resources

b. Dependent Variable: Non-Financial Firm Performance

The regression results in Table 8 indicate a statistically significant model (p-value $=0.012$ ). The results indicate that 19.3 percent of variation in non-financial performance was explained by tangible resources. The remaining 80.7 percent was explained by other factors not considered in the study. The variation coefficient was also significant $(p$-value $=0.012)$. The hypothesis that tangible resources do not influence non-financial performance was rejected.

Intangible resources were defined in terms of reputation, capabilities, culture, technology and knowledge. Both theoretical and empirical studies have shown that intangible resources are the most important for a firm as they are difficult to imitate (Barney, 1991; Hitt et al., 2001). Amit and Schoemaker (1993) proposed that intangible resources were most likely to be a source SCA as opposed to tangible resources. Based on this proposition, the following sub hypothesis was formed for testing.

$H_{01 b}$ : Intangible organizational resources do not have statistical significant influence on performance of insurance companies in Kenya.

The study employed 15 statements that required respondents to indicate to what extent their firms possessed the intangible resources. Table 9 shows regression results for influence of intangible resources on profit before tax.

Table 9. Influence of intangible resources on profitbefore tax

\begin{tabular}{lllllll}
\hline Model & $\mathrm{R}$ & R Square & Adjusted R Square & Std. Error of the Estimate & \\
\hline 1 & $.204^{\mathrm{a}}$ & .041 & .167 & & 2.27952 & \\
\hline ANOVA $^{\mathrm{b}}$ & \multicolumn{7}{l}{} & & \\
\hline Model & & Sum of Squares & Df & Mean Square & F-value & Sig. \\
\hline 1 & Regression & 5.174 & 5 & 1.035 & .199 & $.960^{\mathrm{a}}$ \\
& Residual & 119.513 & 23 & 5.196 & & \\
& Total & 124.687 & 28 & & & \\
\hline
\end{tabular}

A. Predictors: (Constant), Culture, Capabilities, Technology, Reputation, Knowledge

B. Dependent Variable: Average Profit 
Results in Table 9 show the coefficient of determination was 0.041 indicating that 4.1 percent variation in profit before tax was accounted for by intangible resources. The remaining 95.9 percent was explained by other factors not considered in the model. The results indicated a statistically not significant model ( $\mathrm{p}$-value $=0.960)$. This means that intangible resources have a statistically not significant influence on average profit.

Table 10 shows regression results for influence of intangible resources on premium.

Table 10. Influence of intangible resources on premium

\begin{tabular}{lllllll}
\hline Model & $\mathrm{R}$ & \multicolumn{1}{c}{$\mathrm{R}$ Square } & & Adjusted R Square & \multicolumn{2}{l}{ Std. Error of the Estimate } \\
\hline 1 & $.384^{\mathrm{a}}$ & .147 & & -.030 & & .32813 \\
\hline ANOVA $^{\mathrm{b}}$ & & & & & \\
\hline Model & & Sum of Squares & $\mathrm{df}$ & Mean Square & F-value & Sig. \\
\hline 1 & Regression & .447 & 5 & .089 & .830 & $.541^{\mathrm{a}}$ \\
& Residual & 2.584 & 24 & .108 & & \\
& Total & 3.031 & 29 & & & \\
\hline
\end{tabular}

A. Predictors: (Constant), Culture, Capabilities, Technology, Reputation, Knowledge

B. Dependent Variable: Premium

The coefficient of determination was 0.147 which indicates that only 14.7 percent of variation in premium was explained by intangible resources. The remaining 85.3 percent was explained by other factors not considered in the study. Results also reveal a statistically not significant model $(\mathrm{p}$-value $=0.541)$ which means that intangible resources have a statistically not significant influence on premium growth. The results reveal statistically not significant results for individual effect of intangible resources on premium growth ( $\mathrm{p}$ - values $>0.05$ ) indicating that variables do not explain changes in premium.

Table 11 shows regression results for influence of intangible resources on customer perspective.

Table 11. Influence of intangible resources on customer perspective

\begin{tabular}{|c|c|c|c|c|c|c|c|}
\hline Model & $\mathrm{R}$ & R Square & \multicolumn{2}{|c|}{ Adjusted R Square } & \multicolumn{3}{|c|}{ Std. Error of the Estimate } \\
\hline 1 & $.475^{\mathrm{a}}$ & .226 & .077 & & .09853 & & \\
\hline \multicolumn{8}{|c|}{$\mathrm{ANOVA}^{\mathrm{b}}$} \\
\hline Model & & Sum o & ares & $\mathrm{df}$ & Mean Square & F-value & Sig. \\
\hline \multirow[t]{3}{*}{1} & Regression & .074 & & 5 & .015 & 1.515 & $.220^{\mathrm{a}}$ \\
\hline & Residual & .252 & & 26 & .010 & & \\
\hline & Total & .326 & & 31 & & & \\
\hline
\end{tabular}

A. Predictors: (Constant), Culture, Capabilities, Technology, Reputation, Knowledge

B. Dependent Variable: Customer Perspective

The coefficient of determination was 0.226 indicating that 22.6 percent of variation in customer perspective was explained by intangible resources. The remaining 77.4 percent was explained by other factors not considered in the study. Results also reveal a statistically not significant model $(\mathrm{p}$-value $=0.220)$. The hypothesis was not rejected indicating that intangible resources do not influence customer perspective. 
Table 12 shows regression results for influence of intangible resources on internal business processes.

Table 12. Influence of intangible resources on internal business processes

\begin{tabular}{|c|c|c|c|c|c|c|c|}
\hline Model & $\mathrm{R}$ & R Square & Adj & d R Square & Std. Error of the & & \\
\hline 1 & $.525^{\mathrm{a}}$ & .276 & .137 & & .10739 & & \\
\hline ANOV & & & & & & & \\
\hline Model & & Sum o & dares & $\mathrm{df}$ & Mean Square & F-value & Sig. \\
\hline 1 & Regression & .114 & & 5 & .023 & 1.983 & $.115^{\mathrm{a}}$ \\
\hline & Residual & .300 & & 26 & .012 & & \\
\hline & Total & .414 & & 31 & & & \\
\hline
\end{tabular}

A. Predictors: (Constant), Culture, Capabilities, Technology, Reputation, Knowledge

B. Dependent Variable: Internal Business Processes

The coefficient of determination was 0.276 which indicates that only 27.6 percent of variation in internal business processes was explained by intangible resources. The remaining 72.4 percent was explained by other factors not considered in the study. Results also show a statistically not significant model ( $\mathrm{p}$-value $=0.115$ ). The hypothesis was not rejected indicating that intangible resources do not influence internal business processes.

Table 13 shows results for influence of intangible resources on learning and growth.

Table 13. Influence of intangible resources on learning and growth

\begin{tabular}{|c|c|c|c|c|c|c|}
\hline Model & $\mathrm{R}$ & R Square & isted R Square & \multicolumn{3}{|c|}{ Std. Error of the Estimate } \\
\hline 1 & $.627^{\mathrm{a}}$ & .393 & & .08203 & & \\
\hline \multicolumn{7}{|c|}{$\overline{\text { ANOVA }^{b}}$} \\
\hline Model & & Sum of Squares & df & Mean Square & F-value & Sig. \\
\hline \multirow[t]{3}{*}{$\overline{1}$} & Regression & .113 & 5 & .023 & 3.371 & $.018^{\mathrm{a}}$ \\
\hline & Residual & .175 & 26 & .007 & & \\
\hline & Total & .288 & 31 & & & \\
\hline \multicolumn{7}{|c|}{ Coefficients $^{\mathrm{a}}$} \\
\hline & & Unstandardized C & oefficients & $\begin{array}{l}\text { Standardized } \\
\text { Coefficients }\end{array}$ & & \\
\hline \multicolumn{2}{|l|}{ Model } & $\bar{B}$ & Std. Error & Beta & t-value & Sig. \\
\hline \multirow[t]{6}{*}{$\overline{1}$} & (Constant) & .291 & .114 & & 2.548 & .017 \\
\hline & Knowledge & -.064 & .242 & -.072 & -.263 & .794 \\
\hline & Capabilities & .146 & .168 & .191 & .873 & .391 \\
\hline & Technology & .034 & .126 & .049 & .267 & .792 \\
\hline & Reputation & .094 & .121 & .154 & .778 & .444 \\
\hline & Culture & .405 & .245 & .428 & 1.652 & .111 \\
\hline
\end{tabular}

a. Predictors: (Constant), Culture, Capabilities, Technology, Reputation, Knowledge

b. Dependent Variable: Learning and Growth

The coefficient of determination was 0.393 which indicates that 39.3 percent of variation in learning and growth was explained by intangible resources. The remaining 60.7 percent was explained by other factors not considered in the 
study. Results also show a statistically significant model ( $\mathrm{p}$-value $=0.018$ ). The results indicate that intangible resources have a significant influence on learning and growth. The hypothesis was rejected with respect to learning and growth and so intangible resources have a statistically significant influence on learning and growth.

The results reveal statistically not significant results for the independent effect of intangible resources on learning and growth (p- values $>0.05$ ). This shows that independently, the variables do not explain the changes in learning and growth.

Table 14 presents regression results for the influence of intangible resources on environment perspective.

Table 14. Influence of intangible resources on environment perspective

\begin{tabular}{lllllll}
\hline Model & $\mathrm{R}$ & R Square & Adjusted R Square & Std. Error of the Estimate & \\
\hline 1 & $.472^{\mathrm{a}}$ & .223 & .074 & & .18088 & \\
\hline ANOVA $^{\mathrm{b}}$ & & & & & & \\
\hline Model & & Sum of Squares & $\mathrm{df}$ & Mean Square & F-value & Sig. \\
\hline 1 & Regression & .244 & 5 & .049 & 1.494 & $.226^{\text {a }}$ \\
& Residual & .851 & 26 & .033 & & \\
& Total & 1.095 & 31 & & & \\
\hline
\end{tabular}

a. Predictors: (Constant), Culture, Capabilities, Technology, Reputation, Knowledge

b. Dependent Variable: Environmental Aspect

The coefficient of determination was 0.223 which indicates that 22.3 percent of variation in environment aspect was explained by intangible resources. The remaining 77.7 percent was explained by other factors not considered in the study. Results also show a statistically not significant model $(\mathrm{p}$-value $=0.226)$ indicating that intangible resources have a statistically not significant influence environmental aspect. The results reveal statistically not significant results for the independent effect of individual intangible resources on environment perspective ( $p$-values $>0.05$ ). This means that the variables do not explain the changes onenvironmental aspect.

Table 15 presents results for the influence of intangible resources on CSR. The coefficient of determination was 0.338 which indicated that 33.8 percent of variation in social responsibility is explained by intangible resources. The remaining 66.2 percent was explained by other factors not considered in the study. The overall model had a p-value of 0.046 indicating that the model was statistically significant and robust to explain results. The results indicate that intangible resources have a statistically significant influence on CSR and the hypothesis was rejected. The beta coefficients for the variables were however, not significant ( $\mathrm{p}$-values $>0.05$ ). This indicates that the independent variables do not explain the changes in CSR.

Table 15. Influence of intangible resources on corporate social responsibility

\begin{tabular}{|c|c|c|c|c|c|c|c|}
\hline Model & $\mathrm{R}$ & R Square & \multicolumn{2}{|c|}{ Adjusted R Square } & \multicolumn{3}{|c|}{ Std. Error of the Estimate } \\
\hline 1 & $.581^{\mathrm{a}}$ & .338 & .210 & & .18944 & & \\
\hline \multicolumn{8}{|c|}{ ANOVA } \\
\hline Model & & Sum o & ares & $\mathrm{df}$ & Mean Square & F-value & Sig. \\
\hline \multirow[t]{3}{*}{1} & Regression & .476 & & 5 & .095 & 2.651 & $.046^{\mathrm{a}}$ \\
\hline & Residual & .933 & & 26 & .036 & & \\
\hline & Total & 1.409 & & 31 & & & \\
\hline
\end{tabular}

A. Predictors: (Constant), Culture, Capabilities, Technology, Reputation, Knowledge

B. Dependent Variable: Corporate Social Responsibility 
In order to test the hypothesis that intangible resources do not influence non-financial performance, a composite index for intangible resources was computed and regressed on the composite index of non-financial performance. Table 16 shows results for the influence of intangible resources on non-financial performance. The $\mathrm{R}^{2}$ was 0.287 meaning that 28.7 percent of variation in non-financial performance is accounted for by intangible resources. The remaining 71.3 percent was explained by other factors not considered in the study.

The overall model had a p-value of 0.002 which is less than 0.05 . The results indicate that intangible resources have a statistically significant influence on non-financial firm performance. The variation coefficient was also significant $(\mathrm{p}$-value $=0.002)$. The hypothesis that intangible resources do not have a statistically significant influence on non-financial performance was rejected.

Table 16. Influence of intangible resources on non-financial performance

\begin{tabular}{|c|c|c|c|c|c|c|c|c|c|c|}
\hline Model & $\mathrm{R}$ & \multicolumn{2}{|c|}{ R Square } & \multicolumn{2}{|c|}{ Adjusted R Square } & \multicolumn{3}{|c|}{ Std. Error of the Estimate } & & \\
\hline 1 & $.536^{\mathrm{a}}$ & & & .263 & & .084 & & & & \\
\hline \multicolumn{11}{|c|}{ ANOVA } \\
\hline Model & & & \multicolumn{2}{|c|}{ Sum of Squares } & df & \multicolumn{2}{|c|}{ Mean Square } & F-value & \multicolumn{2}{|l|}{ Sig. } \\
\hline \multirow[t]{3}{*}{1} & Regre & & .087 & & 1 & & .087 & 12.077 & \multicolumn{2}{|l|}{$.002^{\mathrm{a}}$} \\
\hline & Resid & & .216 & & 30 & & \multicolumn{2}{|c|}{.007} & & \\
\hline & Total & & .302 & & 31 & & & & & \\
\hline \multicolumn{11}{|c|}{ Coefficients } \\
\hline \multirow[b]{2}{*}{ Model } & & & & \multicolumn{5}{|c|}{$\begin{array}{r}\text { Standardized } \\
\text { Unstandardized Coefficients Coefficients }\end{array}$} & \multirow[b]{2}{*}{ t-value } & \multirow[b]{2}{*}{ Sig. } \\
\hline & & & & \multicolumn{2}{|l|}{$\mathrm{B}$} & Std. Error & Beta & & & \\
\hline \multirow[t]{2}{*}{1} & \multicolumn{3}{|c|}{ (Constant) } & .316 & & .114 & & & 2.772 & .009 \\
\hline & \multicolumn{3}{|c|}{ Intangible Resources } & \multicolumn{2}{|l|}{.551} & .159 & \multicolumn{2}{|l|}{.536} & 3.475 & .002 \\
\hline
\end{tabular}

A. Predictors: (Constant), Intangible Resources

B. Dependent Variable: Non-Financial Performance

To be able to test the main hypothesis that stated that organizational resources do not influence performance, a composite index of both tangible and intangible resources combined was regressed on the composite index of non-financial performance indicator.

The combination of tangible and intangible organizational resources against non-financial firm performance yielded the results as shown in the Table 17.

Table 17. Influence of organization resources on non-financial firm performance

\begin{tabular}{lllllll}
\hline Model & $\mathrm{R}$ & R Square & Adjusted R Square & & \multicolumn{2}{l}{ Std. Error of the Estimate } \\
\hline 1 & .586 & .343 & .321 & & .08136 & \\
\hline ANOVA & & & & & & \\
\hline Model & & Sum of Squares & df & Mean Square & F-value & Sig. \\
\hline 1 & Regression & .104 & 1 & .104 & 15.683 & .000 \\
& Residual & .199 & 30 & .007 & & \\
& Total & .302 & 31 & & & \\
\hline
\end{tabular}




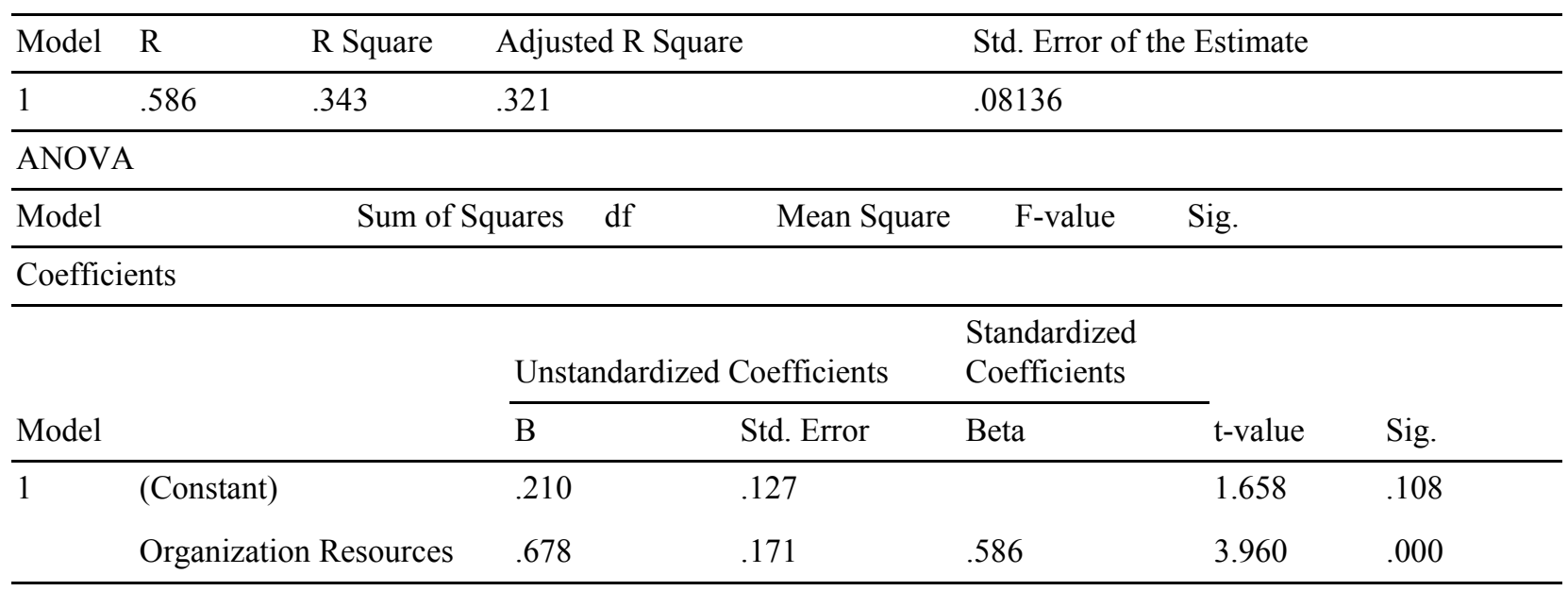

Predictors: (Constant), Organization Resources

Dependent Variable: Non-Financial Performance

Results in Table 17 indicate that the coefficient of determination was 0.343 indicating that 34.3 percent variation in non-financial performance was explained by both tangible and intangible resources. The remaining 65.7 percent was explained by other factors not included in the study. The overall model had a p-value of 0.000 indicating that the model was statistically significant. The hypothesis that organizational resources do not influence performance of insurance companies in Kenya was rejected. Organizational resources had a beta coefficient of 0.586 with a p-value of 0.000 indicating that a unit change in organizational resources causes a change of 0.586 in non-financial performance.

\section{Discussion}

The study hypothesized that there was a statistically significant relationship between organizational resources and performance of insurance companies in Kenya. This was based on the premise that the relationship between resources and firm performance has been established by different scholars as evidenced in the literature review. The extant literature reveals that there is a positive relationship between resources that a firm owns and its performance (Barney, 1999). Strategic management scholars and practitioners posit that resources are the primary predictors of a firm's superior performance (Wernerfelt, 1984; Barney, 1999). According to the extant literature, not all resources a firm possesses have the potential to provide the firm with a SCA (Clulow, 2007). The study sought to empirically investigate further the relationship between resources and performance of insurance companies in Kenya.

With respect to the individual effect of tangible resources on the various performance indicators, the findings were mixed. The study reported statistically significant influence of tangible resources on premium, internal business processes, environment aspect and CSR. Statistically not significant results were observed for profit, customer perspective and learning and growth. This indicated that, tangible resources significantly influence premium but do not significantly influence profit.

Conversely, when the composite index of tangible resources was regressed on the composite of non-financial performance measure, the results indicated an $\mathrm{R}^{2}$ of 0.193 which was lower as compared to the $\mathrm{R}^{2}$ of some of the individual effect results. This was an indicator that individually, tangible resources had a higher contribution to non-financial performance than when combined.

The results for the individual effect of intangible resources on various firm performance indicators were statistically not significant for premium, profit, customer perspective, internal business processes and environment aspect. Statistically significant results were obtained for learning and growth and corporate social responsibility. However, when the composite index for intangible resources was regressed on the composite index of non-financial performance, the study established statistically significant influence of intangible resources on non-financial performance. This means that the various attributes may not have a significant effect on non-financial performance as individual variables. However, in combination, they had a significant influence.

This study established that when the composite index of tangible and intangible resources was regressed on non-financial performance; there was a statistically significant relationship between organizational resources and 
non-financial performance of insurance companies in Kenya. However, intangible resources had a higher contribution to non-financial performance of insurance companies in Kenya as compared to the tangible resources.

These results compare well to both local and international studies. In their empirical study of 93 Israeli firms, Carmeli and Tishler (2004b) found that intangible resources (managerial skills, organizational culture, organizational communication, and perceived organizational reputation) were a source of superior firm performance. Of the four variables, their study established that reputation had the highest contribution to firm performance. Fombrun (1996) argued that publics will prefer to enter into a contract with a firm with a favorable reputation, and would be willing to pay a reasonable premium to do so.

These results suggest that in order for insurance companies to achieve a SCA, they need not only to invest in tangible resources but need to put more emphasis on intangible resources that are hard to imitate. Insurance firms should ensure that they have a good reputation as it is the firm's image that draws stakeholders to the organization. Employees, customers, suppliers, investors and the general public will be attracted to a firm that has a positive image.

The results of this study lend support to Kaplan and Norton's (1996) BSC perspective of measuring a firm's performance using both financial and non-financial performance indicators. Kaplan and Norton noted that financial indicators were subjective and for firms to better measure their performance, they need to focus on non-financial performance. Non-financial performance measures are important to firms as they not only focus on shareholders but on all the firms' stakeholders. If all stakeholders' expectations are met, the firms will be in a better position to experience better performance.

In this study, when intangible resources were combined, their influence on non-financial performance was statistically significant. However, when the study sought to establish if individual resources influenced performance, there were mixed findings. This is consistent with Hult and Ketchen (2001) who posited that no single resource had a positive advantage on performance. They content that when resources are used in combination, they are a source of superior performance. The results contribute to the RBT by indicating to managers of insurance firms that it is how resources are combined that leads to a competitive advantage. It is the bundling/re-bundling and configuration of resources by managers that will lead to superior performance in line with (Penrose 1959).

With respect to financial performance measures, the study found a statistically not significant relationship between organizational resources and profit before tax and premium. These results indicate that for insurance companies, premium and profit (financial performance) are not driven by resources. Other factors might come in to play. For instance, in the recent past due to acts of terrorism, insurance companies have increased their premiums due to customers wanting to insure their properties against terrorism. Other factors that might be driving profitability in insurance companies are high income, instability (terrorism) and IRA fixing minimum premiums payable. Conversely, the study established that non-financial performance of insurance companies was accounted for by organizational resources. This indicates that managers of these companies should focus on non-financial performance measurement.

\section{Implications of the Study}

The results of the study have implications on theory, policy, practice and methodology.

The study came up with findings that will enhance the understanding of the drivers of performance in insurance companies in Kenya. The results of this study contribute to strengthening the existing body of literature by confirming empirically that organizational resources influence performance of insurance companies in Kenya .The study contributes to strategic management theory by establishing the specific resources and their influence on both financial and non-financial firm performance.

Findings of this study have policy implications for insurance companies in Kenya. The insurance industry is one of the key sectors identified to help spur economic growth and help achieve the country's Vision 2030. The performance of the insurance industry is important and therefore the results of this study will assist policy makers to make sound decisions regarding which variables to focus on in order for firms to achieve a SCA. Managers of insurance firms should be encouraged to attract resources that cannot be easily imitated as they propel organizations to better performance.

Organizational resources have been proposed to be important drivers of a firm's success. The results of this study have empirically established the variables that lead to CA. For insurance companies, the study suggests that the key success factors or drivers of better performance are resources owned and controlled by the firm. This study suggests that it is imperative for insurance companies to have strategic resources that are rare, valuable inimitable and non-substitutable in order to gain SCA that in turn lead to improved firm performance. 
Further, the results show that managers need to focus on intangible resources as the study established that they contributed more to performance as compared to tangible resources. In particular, managers should focus on improving their reputation as this gives the stakeholders a positive image of the firm. A good image draws investors, suppliers, employees and customers to the firm leading to improved performance.

The study established that some resources had a higher influence on performance individually than when combined. Managers will need to focus on and understand the drivers of performance and those that hinder performance and focus on acquiring and guarding specific resources. The study proposes that insurance firms should focus on non-financial performance measures and not just financial performance indicators for a balanced and more focused and holistic approach.

To carry out this study, both quantitative and qualitative data were used. Similarly, the study utilized both financial and non-financial measures of performance. In this light, the study used the SBSC to measure firm performance. When regression analysis was carried out, the results did not provide statistically significant results for all the hypotheses. This study provides a platform for testing theoretical foundations to provide quantitative support for theory. The study proposes that a stakeholder approach should be used when measuring performance to ensure a holistic approach.

Scholars have argued that using mixed methods in carrying out research is beneficial as it avoids the two extremes and prevents the limitations that occur when a researcher uses one method. By using the triangulation approach, the study has demonstrated that researchers can overcome the shortcomings of a single method. The triangulation approach was very useful for the success of this study since when one indicator returned not significant results the other indicator evidenced statistically significant results.

\section{References}

Ahanger, R. G. (2011). The relationship between intellectual capital and financial performance: An empirical investigation in an Iranian company. African Journal of Business Management, 5(1), 88-95.

Amit, R., \& Schoemaker, P. (1993).Strategic assets and organizational rent. Strategic Management Journal, 14(1), $33-46$.

Argenti, P., \& Druckenmiller, B. (2009). Reputation and the corporate brand. Tuck School of Business at Dartmouth: Working Paper No. 03-13.

Bakar, L. J. A., \& Ahmad, H. (2010). Assessing the relationship between firm resources and product innovation performance: A resource based view. Business Process Management Journal, 16(3), 420-435.

Barnett, M. L., Jermier, J. M., \& Lafferty, B. A. (2006). Corporate reputation: The definitional landscape (Electronic Edition). Corporate Reputation Review, 9.

Barney, J. B. (1986). Organizational culture: Can it be a source of SCA. Academy of Management Review, 11(3), 656-665.

Barney, J. B. (1991). Firm resources and sustained competitive advantage. Journal of Management, 17(1), 99-120.

Barney, J. B. (1997). Gaining and sustaining competitive advantage. Reading: Addison-Wesley.

Baxter, R., \& Matear, S. (2004). Measuring intangible value in business-to-business buyer-seller relationships: An intellectual capital perspective. Industrial Marketing Management, 33(6), 491-500.

Bornemann, M. (1999). Empirical analysis of the intellectual potential of value systems in Austria according to the VAIC.

Carmeli, A., \& Tishler, A. (2004b). Resources, capabilities and the performance of industrial firms: A multivariate analysis. Managerial and Decision Economics, 25, 299-315.

Castrogiovanni, G. J. (1991). Environmental munificence: A theoretical assessment. Academy of Management Review, $16,542-565$.

Chatterjee, S., \& Wernerfelt, B. (1991). The link between resources and type of diversification: Theory and evidence. Strategic Management Journal, 12, 33-48.

Clarke, C. J. (1988). Using finance for competitive advantage. Long Range Planning, 20(2), 63-69.

Cohen, J., Cohen, P., West, G. S., \& Aiken, L. S. (2003).Applied multiple regression/correlation analysis for the behavioral sciences ( $3^{\text {rd }}$ ed.). Mahwah, New Jersey: Lawrence Erlbaum Associates, Inc. 
Conner, T. (2002). The resource-based view of strategy and its value to practicing managers. Strategic Change, 11, 307-316.

Cooper, D. R., \& Schindler, P. S. (2006). Business research methods (9th ed.). NY: McGraw-Hill.

Crepon, B., Duguet, E., \& Mairesse, J. (1998). Research, innovation and productivity: An econometric analysis at the firm level. Economics of Innovation and New Technology, 7(2), 115-158.

Cucculelli, M., \& Ermini, B. (2012). New product introduction and product tenure: What effects on firm growth? Research Policy, 41, 808-821.

Darfus, P. J., Maggit, P. G., Grimm, C. M., \& Smith, K. G. (2008). The red queen effect: Competitive actions and firm performance. Academy of Management Journal, 51(1), 61-80.

Dess, G. G., \& Picken, J. C. (2000). Changing roles: Leadership in the 21st century. Organizational Dynamics, 28, 18-34.

Dess, G. G., \& Robinson, R. B. Jr. (1984). Measuring organizational performance in the absence of objective measures: The case of the privately-held firm and conglomerate business unit. Strategic Management Journal, 5, $265-273$.

Dierickx, I., \& Cool, K. (1989).Asset stock accumulation and sustainability of competitive advantage. Management Science, 35, 1504-1511.

Edvinsson, L., \& Malone, M. S. (1997). Intellectual capital: The proven way to establish your company's real value by measuring its hidden brainpower. London: Judy Piatkus.

Elkington, J. (1997). Cannibals with forks: The triple bottom line of 21st century business. Oxford: Capstone.

Farjoun, M. (1998). The independent and joint effects of the skill and physical bases of relatedness in diversification. Strategic Management Journal, 19, 611-630.

Freeman, E. (1984). Strategic management: A stakeholder approach. Boston: Pitman.

Gartner, W. B. (1985). A conceptual framework for describing the phenomenon of new venture creation. Academy ofManagement Review, 10, 696-706.

Grant, R. M. (1991). The resource based theory of competitive advantage. California Management Review, 33, $114-$ 135 .

Grant, R. M. (2001). The resource based theory of competitive advantage: Implications for strategy formulation. California Management Review, 1-22.

Hall, R. (1992). The strategic analysis of intangible resources. Strategic Management Journal, 13, 135-144.

Hofer, C. W. (1983). ROVA: A new measure for assessing organizational performance. In R. Lamb (Ed.), Advances in Strategic Management (Vol. 2, pp.43-55). New York: JAI Press.

Hubbard, G. (2009). Measuring organizational performance: Beyond the triple bottom-line. Business Strategy and the Environment, 19, 177-191.

Hult, G. T. M., \& Ketchen, D. J. Jr. (2001). Does market orientation matter? A test of the relationship between positional advantage and performance. Strategic Management Journal, 22, 899-906.

Hunt, C. B., \& Auster, E. R. (1990). Proactive environmental management: Avoiding the toxic trap. Sloan Management Review, 31(2), 7-18.

Ismail, A. I., Rose, R. C., Uli, J., \& Abdullah, H. (2012). The relationship between Organizational resources, capabilities, systems and competitive advantage. Asian Academy of Management Journal, 17(1), 151-173.

Itami, H. (1987). Mobilizing invisible assets. Cambridge, MA: Harvard University Press.

Iwu-Egwuonwu, R. C. (2011). Corporate reputation \& firm performance: Empirical literature evidence. International Journal of Business and Management, 6(4), 1-10.

Johnson, G., Scholes, K., \& Whittington, R. (2008). Exploring corporate strategy: Texts and cases. Boston: Prentice Hall Inc.

Jugdev, K., \& Mathur, G. (2012). Classifying project management resources by complexity and leverage. International Journal of Managing Projects in Business, 5(1), 105-124.

Kapelko, M. M. (2009). Intangible assets and firm efficiency: International analysis in the textile and apparel industry. (Published PhD Thesis). University of Autonona de Barcelona. 
Kaplan, R. S., \& Norton, D. P. (1992). The balanced scorecard: Measures that drive performance. Harvard Business Review, 70(1), 71-79.

Kaplan, R. S., \& Norton, D. P. (1996). The balanced scorecard: Translating strategies into action. Boston, MA: Harvard BusinessSchool Press.

Kostopoulos, K. C., Spanos Y. E., \&Prastacos, G. P. (2002). The resource - based view of the firm and innovation: Identification of critical linkages. The 2nd European Academy of Management Conference, Stockholm.

Kotler, P. (1991). Marketing management (7th ed.). Englewood Cliffs, New Jersey: Prentice-Hall.

Kraatz, M. S., \& Zajac, E. J. (2001). How organizational resources affect strategic change and performance in turbulent environments: Theory and evidence. Organization Science, 12, 632-657.

Lee, C., Lee, K., \& Pennings, J. M. (2001). Internal capabilities, external networks, and performance: A study on technology-based ventures. Strategic Management Journal, 22, 615-640.

Marino, K. E. (1996). Developing consensus on firm competencies and capabilities. Academy of Management Executive, 10(3), 40-51.

Michailova, S., \& Hutchings, K. (2006). National cultural influences on knowledge sharing: A comparison of China and Russia. Journal of Management Studies, 43(3), 383-405.

Morgan, N. A., Kaleka, A., \& Katsikeas, C. S. (2004). Antecedents of export venture performance: A theoretical model and empirical assessment. Journal of Marketing, 68, 90-108.

Mugenda, O. M., \& Mugenda, A. G. (2003). Research methods, qualitative and quantitative approaches. Nairobi: African Centre for Technology Studies.

Nachmias, C. F., \& Nachmias, D. (2004). Research methods in the social sciences (5th ed.). India: Replica Press.

Nelson, R. R., \& Winter, S. G. (1982). An evolutionary theory of economic change. Cambridge: Belknap Press/Harvard University Press.

Nonaka, I. (1994). A dynamic theory of organizational knowledge creation.Organization Science, 5, 14-37.

Nonaka, I., \& Konno, N. (1998). The concept of 'Ba': Building a foundation for knowledge creation. California Management Review, 40, 40-54.

Nonaka, I., \& Takeuchi, H. (1995). The knowledge-creating company: How Japanese companies create the dynamics of innovation. New York, NY: Oxford University Press.

Nunnally, J. C. (1978). Psychometric theory (2nd ed.). New York: McGraw-Hill.

Pandey, I. M. (1999). Financial management (8th ed.). Vikas Publishing House: New Delhi.

Penrose, E. (1959). The theory of the growth of the firm (3rd ed.). Oxford: Oxford University Press.

Peters, T. J., \& Waterman, R. H. (1982). In search of excellence. New York: Harper and Row.

Porter, M. E. (1991). Towards a dynamic theory of strategy. Strategic Management Journal, 12(Special Issue), 95117.

Rubin, P. H. (1973). The expansion of firms. Journal of Political Economy, 84, 936-949.

Schein, E. H. (2004). Organizational culture and leadership. San Francisco, CA: Jossey-Bass.

Senge, P. (1990). The fifth discipline: The art and practice of the learning organization. New York: Doubleday.

Soh, P. H. (2003). The role of networking alliances in information acquisition and its implications for new product performance. Journal of Business Venturing, 18, 727-744.

Stewart, T. A. (1997). Intellectual capital - The new wealth of organizations (1st ed.). London: Nicolas Brealey Publishing.

Teece, D. J., Pisano, G., \& Shuen, A. (1997). Dynamic capabilities and strategic management. Strategic Management Journal, 18(8), 509-533.

Thompson, J. D. E. (1967). Organizations in action. New York: McGraw-Hill.

Zack, M. H. (1999). Developing a knowledge strategy.California Management Review, 41(3), 125-145.

Zott, C. (2003). Dynamic capabilities and the emergence of intra-industry differential firm performance: Insights from a simulation study. Strategic Management Journal, 24, 97-125. 